\title{
IMPLEMENTASI PROGRAM JARING PENGAMAN SOSIAL PADA MASA PANDEMI COVID-19 DI PEKANBARU
}

\author{
Hidayati Nasrah, Irdayanti, Yessi Nesneri, Fitri Hidayati \\ Universitas Islam Negeri Sultan Syarif Kasim \\ hidayati.nasrah@uin-suska.ac.id
}

\begin{abstract}
This research tries to describe how the social safety net program, especially during the pandemic Corona virus in Pekanbaru, which has been going on for quite long. The method used in this research is a qualitative with descriptive analysis. Data collection techniques used were interviews, observation and documents related to the implementation of the assistance program. Furthermore, the data is processed through triangulation techniques. To analyze this implementation policy, the implementation theory of Van Meter and Van Horn is used by looking at 6 indicators of success they are goals, resources, implementing agents, implementing agent attitudes, agent communication and external environment. The results show that the implementation of the assistance program during the Covid-19 pandemic has been running from April 2020 to Desember 20202 when the program objectives were set. However, there is no similarity in implementation based on procedures due to factors, including the expansion of several sub-districts and the absence of a standard measure of success in implementing this assistance program in Pekanbaru.
\end{abstract}

Key words: Corona Virus Pandemi, implementation and social safety net

\begin{abstract}
Abstrak
Penelitian ini mencoba untuk menggambarkan bagaimana program jaring pengaman sosial khususnya di masa pandemi penyebaran virus Corona di Pekanbaru yang telah berlangsung cukup lama. Metode yang digunakan dalam penelitian ini adalah metode Kualitatif dengan analisa deskriptif. Teknik pengumpulan data yang digunakan adalah wawancara, observasi dan dokumen terkait pelaksanaan program bantuan. Selanjutnya data diolah melalui teknik triangulasi. Untuk menganalisis kebijakan implementasi ini digunakan teori Implementasi dari Van Meter dan Van Horn dengan melihat 6 indikator keberhasilan, yaitu tujuan, sumber daya, agen pelaksana, sikap agen pelaksana, komunikasi agen dan lingkungan ekternal. Hasil penelitian menunjukkan bahwa pelaksanaan program bantuan selama pandemi covid telah berjalan dari awal ditetapakan tujuan program yaitu pada bulan April 2020 hingga Desember 2020. Namun belum ada kesamaan dalam pelaksanaan berdarkan prosedur disebabkan faktor antara lain terjadi pemekaran beberapa kecamatan serta untuk belum adanya standar tolak ukur keberhasilan dalam pelaksanaan program bantuan ini di Pekanbaru.
\end{abstract}

Kata kunci: Pandemi covid-19, implementasi dan jaring pengaman sosial 


\section{PENDAHULUAN}

Perkembangan penyebaran Corona Virus Disease 2019 (covid-19) terus meningkat di Indonesia. Sejak awal kemunculannya pada bulan Maret 2020, untuk pertama kalinya pemerintah pusat mengumumkan kasus pertama penderita covi-19 pada tanggal 2 Maret 2020, dan kemudian pada tanggal 13 Maret 2020 dikeluarkan Keputusan Presiden Nomor 7/2020 tentang pembuatan Rapid Response Team yang dipandu oleh Kepala Tubuh Nasional Penanggulangan Musibah (BNPB) yang mengatakan covid-19 sebagai bencana non alam (pandemi) dan selang dua minggu dari kasus pertama, jumlah pasien positif COVID-19 di Indonesia tercatat sudah berjumlah 69 orang (Vermonte \& Wicaksono, 2020) hingga penghujung tahun 2020 pemerintah terus mengumumkan jumlah angka yang terjangkit virus Corona yang semakin tidak terkendali.

Melihat fakta di lapangan yang menunjukkan cepatnya penyebaran virus tersebut, pemerintah melalukan berbagai cara untuk menahan lajunya angka pasien positif covid-19, seperti memebentuk tim satuan tugas penanggulanagan covid-19 yang dipimpin langsung oleh Presiden, meminta pemerintah daerah untuk membuat kebijakan yaitu belajar dari rumah untuk pelajar dan mahasiswa. Kemudian, dengan bermacam pertimbangan, akhirnya Presiden Jokowi menetapkan peraturan tentang Pembatasan Sosial Berskala Besar lewat Peraturan Pemerintah( PP) No 21 Tahun 2020 tentang Pembatasan Sosial Berskala Besar (PSBB). Tidak hanya itu, Presiden juga menerbitkan Keputusan Presiden No 11 Tahun 2020 tentang Penetapan Kedaruratan Kesehatan Warga Covid- 19 dengan atensi utama pemerintah merupakan kesehatan warga.

Kajian ini akan menganalisis tentang implementasi program jaring pengaman sosial yang dilakukan pemerintah kepada masyarakat selama masa pandemi covid-19. Dengan melihat fakta di lapangan yang menunjukkan cepatnya penyebaran virus tersebut, pemerintah melakukan berbagai cara dalam menahan lajunya angka pasien covid-19 antara lain membentuk tim satgas tugas penanggulangan covid-19 yang dipimpin langsung oleh Presiden, meminta 
pemerintah daerah untuk membuat kebijakan yaitu belajar dari rumah untuk pelajar dan mahasiswa. Kemudian, dengan bermacam pertimbangan, akhirnya Presiden Jokowi menetapkan peraturan tentang Pembatasan Sosial Berskala Besar lewat Peraturan Pemerintah (PP) No 21 Tahun 2020 tentang Pembatasan Sosial Berskala Besar (PSBB). Tidak hanya itu, Presiden juga menerbitkan Keputusan Presiden No 11 Tahun 2020 tentang Penetapan Kedaruratan Kesehatan Warga Covid- 19 dengan atensi utama pemerintah merupakan kesehatan warga.

Setelah kebijakan pembatasan sosial dilakukan pemerintah, sepertinya tidak mudah untuk dijalankan selain dituntut peran serta masyarakat untuk mewujudkannya agar efektif dan berhasil. Dalam pelaksanaannya menurut (Wiranti, Sriatmi, \& Kusumastuti, 2020) masih banyak masyarakat yang tidak patuh dan kasus covid-19 makin meningkat, selain itu PSBB memunculkan dampak yang dominan negatif khususnya dibidang ekonomi dan sosial yaitu terhambatnya aktivitas masyarakat menjalani aktivitas dan interaksi secara fisik menjadi berkurang. Selain itu, menurut (Hadirwardoyo, 2020) terdapat 3 aktor yang mengalami kerugian dalam pelaksanaan PSBB, mereka adalah pertama, negara yang mengalami kerugian karena pendapatan menurun khususnya dari pajak sedangkan belanja negara meningkat untul mengatasi kondisi darurat, menyediakanjaring pengaman sosial, mengatasi penderita sakit, pengerahan aparat dan tenaga kesehatan ekstra, membayar bunga utang baru. Kedua, pelaku usaha bisnis, yang kehilangan pendapatan karena tidak ada penjualan (Nasruddin \& Haq, 2020), pemutusan hubungan kerja karyawan dan yang paling buruk adalah kebangkrutan. Ketiga, indivudu yang kehilangan gaji karena kehilangan pekerjaan, bunga utang baru apabila menggunakan dana talangan. Hingga akhir Juli 2020 jumlah pemutusan kerja maupun dirumahkan mencapai 3,5 juta lebih (Karunia, 2020).

Menjawab problematika tersebut, usaha pemerintah tidak berhenti pada kebijakan PSBB, sejumlah inovasi program disiapkan dan dijalankan guna memberikan jalan keluar terhadap permasalahan mendasar yang dihadapi masyarakat Indonesia. Upaya pemerintah menjawab problematika akibat pandemi diwujudkan dalam Program Jaring Pengaman Sosial bagi Kelurga Miskin yang 
rentan terdampak covid-19. Bantuan ini diharapkan mampu untuk meringankan beban masyarakat yang ekonominya terdampak pandemi. Bantuan ini juga bertujuan untuk meningkatkan kembali laju ekonomi yang mulai tumbuh minus 5,3 persen pada kuartal II 2020 (Ihsanuddin, 2020). Menurut Menteri Sosial Juliari P. Batubara, yang dikutip dari laman (www.setkab.go.id, 2020) menjelaskan pemberian jaring pengaman ssosial (bansos) secara reguler dan khusus. Pertama, progres dari penyaluran bantuan sosial reguler yakni Program Keluarga Harapan dan Program Kartu Sembako (non tunai). Kedua, program khusus seperti pembebasan dan diskon tarif listik, insentif bagi pekerja yang memiliki pendapatan di bawah 5 juta dan kebijkan lainnya.

Dikeluarkannya kebijakan pemerintah pusat yang kemudian diturunkan kepada pemerintah daerah sebagai wilayah siaga covid-19, memiliki tugas membagikan penyuluhan kepada masyarakat tentang bahaya covid-19 dan mempersiapkan dana talangan sosial untuk warga. Tetapi terjadi ketidakjelasan dana yang wajib dikeluarkan untuk pengaman sosial ini seperti dana desa yang dapat digunakan buat Bantuan Langsung Tunai (BLT) namun yang membuat bimbang merupakan pada kriteria BLT dimana dalam poin 1 terdapat kriteria miskin namun bukan sebab akibat covid-19, serta pada poin ke 7 terdapat yang tidak boleh menerima dorongan BLT dari dana desa ialah yang menerima bantuan dari pemerintah kabupaten, provinsi serta pusat, dan lainnya. Kalimat dan lainnya ini mempunyai makna rancu serta tidak tegas (Mufida, 2020).

Pada banyak provinsi seperti Riau, progres pembenahan jaring pengaman sosial terlihat lambat dan berdampak pada realisasi anggaran covid-19, masalah yang timbul adalah terkendala data. Pemerintah masih ragu untuk merujuk data dari Badan Pusat Statistik (BPS) atau dinas sosial. Jika merujuk pada BPS datanya sudah lama, sedangkan data pemerintah ketika digunakan untuk penyaluran dana, timbulnya masalah tiak tepat sasaran di lapangan. Dimana untuk bantuan sosial selama pandemi memiliki syarat yang bermacamam-macam. Secara keseluruhan alokasi anggaran penanganan covid-19 di Riau mencapai Rp.474 milliar dengan rincian penanganan kesehatan, jaring pengamana sosial dan pemulihan ekonomi. Adapun realisasi mencapai 45 persen (Kurnia, 2020). 
Seperti dilansir dari (www.pekanbaru.go.id, 2020)pemerintah Kota Pekanbaru telah melaksanakan pemberian dana bantuan kepada masyarakat, yang terdiri dari Program Keluarga Harapan (PKH) dan Bantuan Pangan Non Tunai (BNPT). Uang bantuan untuk kelompok masyarakat miskin akan ditransfer langsung ke rekening. Selama masa PSBB terdapat 3 golongan masyarakat yang mendapatkan bantuan dari pemerintah. Pertama, kelompok masyarakat miskin yang mendapat bantuan dana dari PKH dan BNPT dari kementrian sosial. Kedua, kelompok masyarakat hampir miskin yang mendapat bantuan BNPT dan ketiga, kelompok masyarakat rentan miskin yang akan mendapatkan bantuan tunai sebesar Rp.600.000 perbulan selama tiga bulan.

Meski berbagai bantuan telah diberikan, banyak diantara masyarakat yang ekonominya belum pulih sejak pandemi. Sejumlah pejabat negara dan pengamat politik memprediksi Indonesia akan mengalami resesi ekonomi. Bantuan dan subsidi yang digulirkan pemerintah dinilai berjangka pendek. Padahal pandemi covid-19 menimbulkan dampak jangka panjang yang membutuhkan dana begitu besar. Jika daya beli masyarakat tidak membaik, maka pertumbuhan ekonomi di Indonesia akan terus minus dan pemerintah akan dihadapkan dengan permasalahan yang baru.

\section{STUDI LITERATUR}

\section{A. Implementasi}

Model pendekatan top-down yang diformulasikan oleh van Metter dan Van Horn dalam Agustino (Agustino, 2016) dengan judul A Model of The Policy Implementation. Proses implementasi ialah suatu abstraksi ataupun performansi dari sesuatu penerapan kebijakan yang pada dasarnya secara terencana dicoba buat mencapai kinerja implementasi kebijakan publik yang berlangsung dalam ikatan dengan bermacam variabel. Model ini mengandaikan jika implementasi kebijakan berjalan baik dari keputusan politik yang ada, pelaksana, serta kinerja kebijakan publik.

Terdapat 6 variabel, bagi van Metter dan Van Horn, yang pengaruhi kinerja implementasi kebijakan publik: 
a) Dimensi serta Tujuan Kebijakan.

Kinerja implementasi kebijakan bisa diukur tingkatan keberhasilannya jika dimensi serta tujuan dari kebijakan cukup realistis dengan sosio- kultur di tingkatan pelaksana kebijakan. Jika dimensi kebijakan sangat utopis untuk dilaksanakan di tingkatan masyarakat, maka akan jauh dari kesuksesan.

b) Sumber daya.

Keberhasilan proses implementasi kebijakan sangat bergantung dari keahlian menggunakan sumber daya yang ada. Manusia ialah sumber energi yang terutama dalam memastikan sesuatu keberhasilan proses implementasi. Implementasi menuntut terdapatnya sumber daya manusia yang bermutu dengan pekerjaan yang diisyaratkan oleh kebijakan yang sudah diresmikan secara politik. Namun di luar sumber daya manusia, sumber- sumber daya lain yang butuh diperhitungkan pula yakni sumber daya finansial serta waktu.

c) Karakteristik Agen Pelaksana.

Pusat atensi pada agen pelaksana meliputi organisasi resmi serta organisasi informal yang hendak ikut serta dalam pengimplementasian kebijakan publik. Perihal ini sangat berarti sebab kinerja implementasi kebijakan (publik) dipengaruhi oleh identitas sesuai dengan para agen pelaksanananya. Misalnya, implementasi kebijakan publik yang berupaya buat merubah sikap manusia secara radikal, hingga agen pelaksana projek itu haruslah berkarakteristik tegas, keras, serta ketat dalam melakukan ketentuan cocok dengan sanksi hukum yang sudah diresmikan. Tidak hanya itu, cakupan ataupun luas daerah implementasi kebijakan butuh diperhitungkan manakala hendak memastikan agen pelaksana. Terus menjadi luas cakupan implementasi kebijakan, hingga sepatutnya terus menjadi besar pula agen yang dilibatkan.

d) Sikap ataupun Kecenderungan (Disposition) Para Pelaksana.

Sikap penerimaan ataupun penolakan dari (agen) pelaksana sangat mempengaruhi keberhasilan ataupun tidaknya kinerja implementasi kebijakan publik. Perihal ini sangat bisa jadi terjadi karena kebijakan yang dilaksanakan tidaklah hasil perumusan masyarakat setempat yang memahami betul perkara serta kasus yang mereka rasakan. Namun kebijakan yang hendak implementor 
laksanakan merupakan kebijakan" dari atas" (top down) yang sangat bisa jadi para pengambil keputusan-nya tidak mengenali kebutuhan, kemauan, ataupun kasus yang masyarakat ingin selesaikan.

e) Komunikasi Antar- Organisasi serta Kegiatan Pelaksana.

Koordinasi ialah mekanisme utama dalam memastikan keberhasilan penerapan kebijakan, Sehingga asumsinya kesalahan hendak sangat kecil terjadi

f) Lingkungan Ekonomi, Sosial, serta Politik.

Perihal terakhir yang butuh pula dicermati guna memperhitungkan kinerja implementasi publik dalam perspektif yang ditawarkan oleh van Metter dan Van Horn yaitu sejauhmana lingkungan eksternal ikut mempengaruhi keberhasilan kebijakan publik yang sudah diresmikan. Lingkungan tersebut adalah lingkungan sosial, ekonomi, serta politik. Lingkungan yang tidak kondusif bisa jadi mempengaruhi kegagalan kinerja implementasi kebijakan. Oleh karena itu, upaya buat mengimplementasikan kebijakan wajib pula mencermati keadaan lingkungan eksternal.

\section{B. Program Jaring Pengaman Sosial (JPS)}

Konsep JPS diperkenalkan oleh kelompok kapitalis pada saat peralihan ekonomi di negara-negara Eropa Timur tahun 1900an. Saat itu terjadi transisi ekonomi dari sistem ekonomi sosialis ke sistem ekonomi pasar. Transisi sistem ekonomi ini mengakibatkan kelompok masyarakat miskin yang selama sistem ekonomi sosialis mendapatkan jatah pangan gratis dari pemerintah menjadi tidak lagi mendapatkan jatah pangan gratis. Bank Dunia menyebutkan bahwa JPS ditujukan melindungi kelompok orang atau keluarga yang mengalami penurunan kapasaitas secara kronis sehingga kehilangan pekerjaan (Sumodiningrat, 1999)

Program JPS selama pandemi Covid adalah program yang dirancang untuk membantu rakyat miskin yang terkena dampak akibat pandemi COVID-19 dan dilaksanakan melalui tahapan penyelamatan dan pemulihan menuju pada kondisi normal. 


\section{Alokasi Dana Jaring Pengaman Sosial}

Alokasi dana jaring pengaman sosial adalah:

1. Pembebasan tarif listrik 450VA dan diskon tarif untuk 900 VA selama 3 bulan

2. Kartu Prakerja berupa insentif sebesar Rp.600.000 kepada 5,6 juta orang per 4 bulan

3. Kartu sembako, diberikan kepada 20 juta penerima, peroranganya mendapatkan Rp.200.000 perbulan untuk 12 bulan.

4. Program Keluarga Harapan (PKH) untuk 10 Juta keluarga penerima manfaat selama 12 bulan

5. Bansos tunai untuk 9 juta keluraga penerima manfaat sebesar Rp.600.000 selama 3 bulan

6. Bansos sembako untuk 1,3 juta keluarga penerima manfaat di Jakarta dan Rp.600.000 untuk 3 bulan di luar penerima PKH, Kartu Sembako, Bansos Tunai dan Prakerja

7. BLT Dana Desa untuk 11 juta keluarga penerima manfaat selama 3 bulan diluar penerima PKH, Kartu Sembako, Bansos Tunai dan Prakerja.

\section{Penelitian Terdahulu}

\begin{tabular}{|c|c|c|c|c|}
\hline No & Penulis & Judul Artikel & Temuan Utama & $\begin{array}{l}\text { Metode } \\
\text { Penelitian }\end{array}$ \\
\hline 1 & $\begin{array}{l}\text { Islami, Athoillah; } \\
\text { Lailiyah Kusroh; } \\
\text { Rizal, M. Syamsul }\end{array}$ & $\begin{array}{l}\text { Problem Efektivitas } \\
\text { Pencegahan Covid- } \\
19 \text { di Indonesia } \\
\text { dalam Perspektif } \\
\text { Sosiologi Hukum } \\
\text { (Studi Analisis } \\
\text { Kebijakan PSBB) } \\
\text { Mimikri: Jurnal } \\
\text { Agama dan } \\
\text { Kebudayaan Vol. } 6 \\
\text { No.2 }\end{array}$ & $\begin{array}{l}\text { Bahwa implementasi kebijakan } \\
\text { PSBB pada beberapa daerah } \\
\text { di Indonesia dalam tataran } \\
\text { praktisnya belum berjalan } \\
\text { dengan efektif. Hal demikian } \\
\text { disebabkan terdapat problem } \\
\text { pada empat aspek dari } \\
\text { kebijakan penerapan PSBB, } \\
\text { yakni kaidah hukum, penegak } \\
\text { hukum, kesadaran masyarakat, } \\
\text { dan sarana (fasilitas }\end{array}$ & $\begin{array}{l}\text { normatif } \\
\text { empiris }\end{array}$ \\
\hline
\end{tabular}




\begin{tabular}{|c|c|c|c|c|}
\hline 2 & Tuwu, Darwin & $\begin{array}{l}\text { Kebijakan } \\
\text { Pemerintah dalam } \\
\text { Penanganan } \\
\text { COVID-19 } \\
\text { Journal Publicuho: } \\
\text { Volume } 3 \text { Number } \\
2 \quad \text { (May-July), } \\
\text { (2020) pp.267 -278 }\end{array}$ & $\begin{array}{l}\text { kebijakan pemerintah untuk } \\
\text { mencegah } \\
\text { penularan virus Corona seperti: } \\
\text { kebijakan berdiam diri di } \\
\text { rumah; Pembatasan Sosial; } \\
\text { Pembatasan Fisik; Penggunaan } \\
\text { Alat Pelindung Diri; Menjaga } \\
\text { Kebersihan Diri; Bekerja dan } \\
\text { Belajar di rumah; Menunda } \\
\text { semua kegiatan } \\
\text { mengumpulkan orang banyak; } \\
\text { Pembatasan Sosial Berskala } \\
\text { Besar; hingga pemberlakuan } \\
\text { kebijakan New Normal. }\end{array}$ & $\begin{array}{l}\text { metode } \\
\text { kualitatif } \\
\text { dengan } \\
\text { pendekatan } \\
\text { studi kasus }\end{array}$ \\
\hline 3 & $\begin{array}{l}\text { Juaningsih, Imas } \\
\text { Novita; } \\
\text { Consuello, Yosua; } \\
\text { Tarmidzi, Ahamd; } \\
\text { Nurlfan, Dzakwan }\end{array}$ & 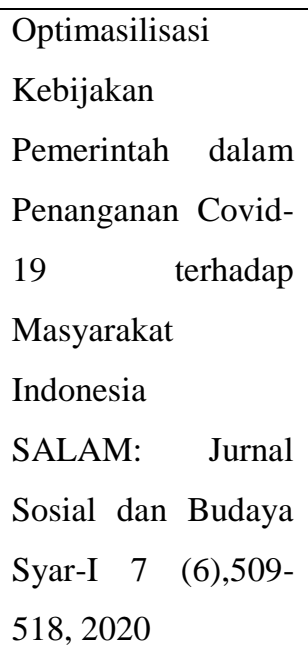 & $\begin{array}{l}\text { Kurang koordinasi antara } \\
\text { pemerintah pusat dan daerah } \\
\text { yang berdampak semakin } \\
\text { tersebarnya virus Covid-19 }\end{array}$ & $\begin{array}{l}\text { Metode } \\
\text { Kualitatif }\end{array}$ \\
\hline 4 & \begin{tabular}{l}
\multicolumn{2}{l}{ Rahmansyah, } \\
Wildan; Qadri, \\
Resi Ariyasa; \\
Sakti, $\quad$ Ressa \\
Anggia; Ikhsan, \\
Syaiful
\end{tabular} & $\begin{array}{l}\text { Pemetaan } \\
\text { Permasalahan } \\
\text { Penyaluran Bantuan } \\
\text { Sosial Untuk } \\
\text { Penanganan Covid- } \\
19 \text { di Indonesia } \\
\text { Jurnal: PKN (Jurnal } \\
\text { Pajak dan } \\
\text { Keuangan Negara } 2 \\
\text { (1), 90-102, 2020 }\end{array}$ & $\begin{array}{l}\text { Permasalahan yang terjadi } \\
\text { dalam panyaluran bantuan } \\
\text { social adalah alokasi anggaran } \\
\text { disetiap kementian berbeda, } \\
\text { masalah data yang tidak } \\
\text { terintegrasi dan masalah dalam } \\
\text { penyaluran bantuan di lapangan. }\end{array}$ & $\begin{array}{l}\text { Studi } \\
\text { Literatur }\end{array}$ \\
\hline
\end{tabular}




\section{METODE PENELITIAN}

Jenis penelitian ini merupakan penelitian kualitatif deskriptif yaitu penelitian berupa pengumpulan informasi berupa dokumen, foto dan bukan angka- angka. Penelitian ini bertujuan untuk mendapat gambaran dan informasi yang lebih jelas, lengkap, serta memungkinkan dan mudah bagi peneliti untuk melakukan penelitian observasi. Penelitian ini difokuskan pada masyarakat yang telah menerima bantauan program pengaman sosial di Pekanbaru dan para agen pelaksana di tingkat daerah melalui metode wawancara dan observasi dan dokumentasi. Pada saat wawancara, penelitit telah melaksanakan analisis terhadap jawaban dari informan melalui reduksi informasi, penyajian dan pernarikan kesimpulan.

\section{HASIL DAN PEMBAHASAN}

\section{A. Tujuan}

Salah satu usaha pemerintah untuk meningkatkan perekonomian Negara akibat adanya pandemi covid-19 adalah ditingkatkannya jumlah Program Jaring Pengaman Sosial kepada masyarakat oleh Kementrian Sosial Nomor 54/HUK/2020 tentang Pelaksanaan Bantuan Sembako dan Bantuan Tunai dalam Penanganan Dampak Covid-19. Tujuan dari kebijakan adalah membantu masyarakat yang terkena dampak pandemi covid dan memicu laju pertumbuhan ekonomi.

Bila dilihat dari pengertiannya, bantuan sosial bisa dikatakan sebagai salah satu tipe belanja pemerintah yang tercantum dalam klasifikasi ekonomi. Belanja bantuan sosial merupakan pengeluaran berbentuk transfer uang, barang ataupun jasa yang diberikan oleh pemerintah pusat/ daerah kepada warga guna melindungi warga dari terjadinya resiko sosial, meningkatkan keahlian ekonomi serta/ ataupun kesejahteraan warga. Penafsiran resiko sosial sendiri merupakan peristiwa ataupun kejadian yang bisa memunculkan potensi terbentuknya kerentanan sosial yang ditanggung oleh orang, keluarga, kelompok, serta/ atau warga akibat krisis sosial, krisis ekonomi, krisis politik, fenomena alam, wabah penyakit serta musibah alam yang bila tidak diberikan belanja bantuan sosial hendak terus 
menjadi terpuruk serta tidak bisa hidup dalam keadaan normal (Dharmakarja, 2017).

Pemerintah telah mengumumkan dilaksanakannya Jaring Pengaman Sosial pada 2 April 2020 untuk menghadapi COVID-19 yang dilakukan melalui pemberian bantuan. Berdasarkan Keputusan Bersama dikeluarkan Peraturan Gubernur Riau Nomor 29 tahun 2020 tentang pedoman bantuan keuangan bersifat khusus kepada kabupaten/kota untuk peningkatan kualitas jaring pengaman sosial dalam penanganan dampak corona virus disease 2019 (covid-19) yang bersumber pada anggaran pendapan dan belanja daerah provinsi Riau tahun anggaran 2020 . Pada pasal 5 bantuan keuangan bersifat khusus digunakan pemerintah kabupaten/kota untuk peningkatan kualitas jaring pengamanan sosial untuk masyarakat terdampak covid-19 dalam bentuk Bantuan Sosial Tunai sebesar Rp.300.000,- (tiga ratus ribu rupiah) untuk setiap kepala keluarga per bulan selama 3 (tiga) bulan dan dapat diperpanjang sesuai kemampuan keuangan daerah.

Berdasarkan data yang didapat dari PT. Pos Indonesia sebagai pihak penyalur bantuan sosial tunai, terdapat 30.267 kepala keluarga di Pekanbaru yang menerima bantuan. Kecamatan Bukitraya 2160 KK, kecamatan Limapuluh 695 KK, kecamatan Marpoyan Damai 4097 KK, kecamatan Payung Sekaki 3069 KK, kecamatan Pekanbaru Kota 1323 KK, kecamatan Rumbai 3584 KK, kecamatan Rumbai Pesisir 1921 KK, kecamatan Sail 436 KK, kecamatan Senapelan 1212 KK, kecamatan Sukajadi 1117 KK, kecamatan Tampan 5895 KK dan kecamatan Tenayan Raya 5776 KK.

Selama pandemi covid-19 banyak masyarakat yang diPHK, dirumahkan atau mengalami pengurangan gaji. Dengan adanya bantuan sosial tunai, masyarakat sangat terbantu memenuhi kebutuhan pokok atau kebutuhan lainnya sehingga kegiatan ekonomi tetap jalan karena daya beli masyarakat tetap hidup.

Di dalam pembagian bantuan sosial tunai terdapat beberapa kendala, pertama dalam penyerahan surat pengambilan seperti surat tersebut tidak sampai ke perima tepat waktu sedangkan untuk mendapatkan bantuan tersebut masyarakat harus membawa surat tersebut dan KTP/KK. Berdasarkan hasil wawancara, hal ini disebabkan info yang sampai ke pihak RT/RW terlambat sedangkan pihak Pos 
Indonesia meyalurkan surat tersebut satu minggu sebelum pengambilan dana. Kedua, terdapat masyarakat yang namanya salah ketik dan NIK yang beda dari KK dan yang ketiga adanya masyarakat yang berkebutuhan khusus atau lansia yang KKnya tunggal sehingga tidak bisa diwakilkan oleh anggota KK lainnya.

Dalam mengatasi masalah tersebut pihak Pos Indonesia melakukan atau memberikan beberapa kemudahan yaitu pertama mengantarkan langsung bantuan tersebut kepada masyarakat yang berkebantuan khusus atau lansia, kedua memberikan waktu tambahan atau jadwal susulan bagi yang ketinggalan info dan yang ketiga memperpanjang jam pembagian, yang sebelumnya sampai pukul 16.00 menjadi pukul 17.00. Dengan adanya kemudahan ini dapat meminimalisir masyarakat yang tidak dapat bantuan.

\section{B. Sumber Daya}

Program Jaring Pengaman Sosial pada masa pandemi covid-19 sudah terlaksana dengan terintegrasinya seluruh sumber daya baik seperti sumber daya manusia, sumber daya finansial dan sumber daya teknologi. Penyaluran Jaring Pengaman Sosial (JPS) kepada masyarakat pada masa pandemi covid -19 dengan kategori yang telah ditetapkan oleh Kementrian Sosial dan Agen Pelaksana sudah terlaksana, hal ini didukung oleh terintegrasi segala sumber daya yang digunakan untuk implementasi kebijakan.

\section{Keuangan}

Program Jaring Pengaman Sosial (JPS) pada masa pandemi covid -19 dapat dilaksanakan berdasarkan Peraturan Menteri Keuangan RI Nomor 38/PMK.02/2020 yaitu untuk melaksanakan ketentuan Pasal 2 ayat (2) Peraturan Pemerintah pengganti Undang-undang Nomor 1 tahun 2020 tentang Kebijakan Keuangan Negara dan Stabilitas Sistem Keuangan untuk Penanganan Pandemi Covid -19 dan atau dalam rangka menghadapi ancaman yang membahayakan perekonomian Nasional dan/atau Stabilitas Sistem Keuangan.

\section{Sumber Daya Manusia}

Penanggung jawab pelaksanaan bantuan sosial sembako dilaksanakan oleh Direktorat Jenderal Perlindungan dan Jaminan Sosial. Begitu juga dengan 
pemerintah daerah provinsi dan pemerintah daerah kabupaten/kota melakukan sosialisasi serta pemantauan dan evaluasi pelaksanaan penyaluran bantuan sosial sembako dan bantuan sosial tunai sesuai dengan wilayahnya dan menyampaikan laporan secara tertulis kepada Menteri Sosial melalui Direktur Jenderal Perlindungan dan Jaminan Sosial serta Direktur Jenderal Penanganan Fakir Miskin. Artinya pemerintah melalui kementriannya memberdayakan potensi jajarannya dalam pelaksanaan kebijakan jaring pengaman ini. Ditambah dengan pihak pemerintah daerah dan koordinator pelaksana kegiatan.

\section{Teknologi}

Pemerintah daerah provinsi dan pemerintah daerah kabupaten/kota melakukan sosialisasi serta pemantauan dan evaluasi pelaksanaan penyaluran bantuan sosial sembako dan bantuan sosial tunai sesuai dengan wilayahnya dan menyampaikan laporan secara tertulis kepada Menteri Sosial melalui Direktur Jenderal Perlindungan dan Jaminan Sosial serta Direktur Jenderal Penanganan Fakir Miskin. Kegiatan ini dilakukan dengan menggunakan teknologi sebagai sarana pemanfaatan yang lebih efektif. Terdapat beberapa website terkait pelaksanaan program yang digunakan pemerintah salah satunya adalah website kementrian:

-Kementrian Sosial: https://www.kemsos.go.id/,

-Program Indonesia Pintar/Kartu Indonesia Pintar Kuliah/Bidikmisi: https://indonesiapintar.kemdikbud.go.id/; https://kipkuliah.kemdikbud.go.id/; https://bidikmisi.belmawa.ristekdikti.go.id/)

- Kartu Pra Kerja (link info : prakerja.go.id)

- Bantuan Langsung Tunai Dana Desa (link info : https://www.kemendesa.go.id/)

\section{Karakter Agen Pelaksana}

Menurut Van Meter dan Van Horn, implementasi yang berhasil membutuhkan mekanisme-mekanisme dan prosedur-prosedur lembaga untuk membantu atasan mendorong bawahan pelaksana untuk bertindak dalam suatu cara yang konsisten dengan ukuran-ukuran dan tujuan-tujuan kebijakan. Mekanisme ini dijalankan oleh para agen pelaksana mencakup struktur birokrasi, 
norma-norma, dan hubungan yang terjadi dalam birokrasi. Menurut Van Meter dan Van Horn organisasi pelaksana memiliki enam variabel yang harus diperhatikan, yaitu: 1 kompetensi dan jumlah staf, 2 rentang dan derajat pengendalian, 3 dukungan politik yang dimiliki, 4 kekuatan organisasi, 5 derajat keterbukaan dan kebebasan komunikasi, dan 6 keterkaitan dengan pembuat kebijakan (Wibawa, 1994)

Karakter agen pelaksana program jaring pengaman sosial selama pandemi mengatur pelaksana penyaluran bantuan sosial khusunya non tunai program keluarga harapan dilaksanakan secara terkoordinasi antar pemerintah pusat, provinsi dan kabupaten/kota. Program jaring pengaman sosial merupakan kebijakan yang dibuat oleh pemerintah untuk memastikan masyarakat mendapatkan bantuan selama masa pandemi covid-19. Dalam proses pelaksanaannya tentu pemerintah memerlukan dukungan dari semua pihak, baik pemerintah yaitu sesama kementrian, dunia usaha, maupun masyarakat sipil yang masuk ke dalamnya adalah Koordinator Daerah. Para peserta kegiatan ini penguatan kapasitas ini berfungsi untuk menjalankan program-program kementrian sosial terlaksana dengan baik. Mereka harus memastikan program sembako patuh pada prinsip, 6T yaitu Tepat sasaran, tepat jumlah, tepat waktu, tepat harga, telat kualitas dan tepat administrasi. Mereka juga mengawal pelaksanaan program penanganan fakir miskin dan mendukung kelancarannya.

Disamping itu para koordinator menangani dan menyelesaian berbagai permasalahan di lapangan, seperti memastikan layanan e-warung, kualitas barang, suplai barang dan permasalahan lainnya. Kementrian Sosial memliki beberapa program seperti program bantuan sosial reguler, berupa perluasan program sembako dan perluasan Program Keluarga Harapan, kemudian ada juga program bantuan sosial penanganan covid-19, yaitu berupa Bantuan Sosial Tunai untuk 9 juta penerima, bantuan sosial tunai kartu sembako non $\mathrm{PKH}$ untuk 9 juta penerima, bantuan presiden berupa sembako dan bantuan sosial beras untuk 10 juta penerima. Untuk mensukseskan program sembako inin diperlukan kesesuaian antar pelaksana dan pemahaman setiap pihak. Dengan menetapkan 153 pendamping koordinator lapangan (Setiawan, 2020). 


\section{Sikap Agen Pelaksana}

Dalam implementasi kebijakan publik, organisasi pelaksana merupakan salah satu faktor penting karena pada dasarnya merujuk pada sistem birokrasi pemerintah. Kedudukan birokrasi memang sangat penting dalam proses implementasi kebijakan publik. Setelah kebijakan publik diformulasikan serta diresmikan, hingga diperlukan terdapatnya sesuatu sistem buat mengimplementasikannya, ialah birokrasi. Lewat birokrasi bisa diselenggarakan berbagai variasi tindakan yang luas, membicarakan serta menyelenggarakan petunjuk, menyelenggarakan pendanaan, menjabarkan informasi, menganalisis permasalahan, membantu serta mempermudah personil, membuat unit- unit operasional dan lain- lain sehingga dibutuhkan sebuah sikap yang konsisten dengan aturan pelaksasanaan.

Sikap penerimaan atau penolakan dari agen pelaksana akan sangat banyak mempengaruhi keberhasilan atau tidaknya kinerja implementasi kebijakan publik. Hal ini terjadi karena kebijakan yang dilaksanakan bukanlah hasil formulasi orang-orang yang terkait langsung terhadap kebijakan yang mengenal betul persoalan dan permasalahan yang dihadapi.

Berdasarkan hasil wawancara dan pengamatan peneliti mengenai proses pelaksanaan program bantuan sosial di kota Pekanbaru sudah sesuai ketentuan undang-undang dan petunjuk tekhnis berdasarkan Keputusan Direktur Jenderal Perlindungan dan Jaminan Sosial Nomor: 03/ LJS/01/2019. Hal ini di dukung oleh pernyataan Ketua RT Kelurahan Tuah madani Kecamatan Tampan Kota Pekanbaru. Zulkarnain, S.Pd pada tanggal 01 Desember 2020 jam 10.00 WIB.

"Bantuan yang diberikan pemerintah, diajukan langsung oleh masyarakat kepada ketua RT, dengan mengisi fomulir yang telah disediakan oleh $R W$. Yang di periksa oleh Program Pemberdayaan Masyarakat Berbasis Rukun Warga (P2MBRW) berdasarkan kriteria-kriteria penerima bantuan yang telah di tetapkan oleh pemerintah"

Adapun tugas pokok dan fungsi koordinator program adalah sebagai berikut:

1. Bertanggung jawab atas pelaksanaan tekhnis program

2. Melakukan kajian konsep dasar program 
3. Melakukan kajian terhadap kebijakan yang tertuang dalam Peraturan Walikota

4. Memastikan rencana penataan kawasan rukun warga.

5. Merancang perencanaan kegiatan pada tiap kelurahan

6. Menjalin kemitraan dengan Lembaga Percepatan Penanggulangan Kemiskinan Daerah/Pusat, SKPD, PKBL/CSR.

7. Meminta/menerima laporan bulanan kinerja dari koordinator Bidang, Koordinator Wilayah Kecamatan dan Pendamping Kelurahan.

8. Mengendalikan dan mengevaluasi kinerja koordinator wilayah kecamatan.

\section{E. Komunikasi Antar Agen}

Komunikasi merupakan salah satu indikator penting dalam penyampaian suatu kebijakan, oleh karenya sebuah kebijakan yang akan disampaikan harus dipahami dengan baik oleh pelaksananya. Sehingga kebijakan tersebut mampu tersampaikan dan disebarkan dengan jelas, akurat dan tidak menimbulkan kesalahpamanan. Berdasarkan hasil observasi dan wawancara bahwa komunikasi antar agen dalam program jaring pengaman di masa pandemi ini terus dilaksanakan. Komunikasi dan koordinasi antara pemerintah daerah, Pendamping dan Koordinator PKH, dan Kementian Sosial terus ditingkatkan. Kendati tidak dapat bertemu dengan tatap muka, namun komunikasi dapat dilakukan secara daring seperti Rakornas. Seperti dikutip dari (www.kabar24.bisnis.com, 2020) Direktur Jenderal Perlindungan dan Jaminan Sosial Pepen Nazarudin menjelaskan setiap Pendamping dan Koordinator Program Keluarga Harapan yang turun ke lapangan ditugaskan untuk memandu pelaksanaan penyaluran bantuan sosial $\mathrm{PKH}$ dengan tetap memperhatikan protokol kesehatan.

"Pendamping dan Koordinator PKH juga berkoordinasi dan bekerja bersama dengan petugas bank penyalur dan agen bank"

Untuk meningkatkan kemampuan para pendamping dan koordinator $\mathrm{PKH}$ dalam memberikan pendampingan kepada masyarakat khususnya di masa pandemi ini, Kemensos melalui Direktorat Jaminan Sosial Keluarga, memberikan 
bimbingan teknis (bimtek) bagi pendamping PKH di seluruh Indonesia dengan sistem daring dan pertemuan. Adapun rakornas PKH diikuti 166 peserta yang terdiri dari Kepala Dinas Sosial Provinsi, Koordinator Regional, dan Koordinator Wilayah di seluruh Indonesia. Tujuan Rakornas PKH adalah untuk membahas isu terkini tentang kinerja SDM PKH, sekaligus meningkatan pengetahuan, keterampilan dan sikap, serta penyaluran bansos PKH per bulan (Nugroho, 2020)

"Kami juga sekaligus berdialog dan memantau secara langsung bagaimana para Pendamping dan Koordinator PKH di lapangan menyosialisasikan bansos PKH"

Dalam penyaluran bantuan sosial dilakukan dalam rangka mendukung program keuangan inklusif di Indonesia, khususnya dalam membangun sistem pembayaran Government-to-People. Oleh karena itu Kementerian Sosial (Kemensos) melakukan perjanjian kerjasama dengan Himbara untuk memberikan kejelasan dalam pelaksanaan penyaluran bantuan sosial melalui perbankan.

Untuk mempermudah Komunikasi Antar agen, maka di perlukan petunjuk tekhnis agar masing-masing agen pelaksana dapat memahami perannya, yakni yang berkaitan dengan kebijakan, alur kerja, prinsip umum, tekhnis operasional dan siapa yang bertanggungjawab dalam setiap peran yang di jalankan.

Petunjuk tekhnis bekaitan dengan pelaksanaan persiapan, pembukaan rekening, sosialisasi dan edukasi, penyaluran serta penarikan bantuan sosial oleh bank penyalur, e-warong, dan Keluarga Penerima Manfaat (KPM) sesuai tugas pokok dan fungsi masing-masing. Petunjuk tekhnis ini dapat digunakan oleh seluruh agen pelaksana yakni : Pemerintah Pusat, Pemerintah Daerah, Bank Penyalur, e-warong dengan mengacu kepada Peraturan Presiden Republik Indonesia Nomor 63 Tahun 2017 tentang Penyaluran Bantuan Sosial Secara Non Tunai dan Peraturan Menteri Sosial Republik Indonesia Nomor 1 Tahun 2008 tentang Program Keluarga Harapan.

\section{F. Lingkungan Sosial, Ekonomi dan Politik}

Indikator terakhir dalam melihat implementasi kebijakan menurut Van Meter dan Van Horn adalah faktor eksternal yang mampu mempengaruhi 
keberhasilan kebijakan. Terdapat beberapa sektor yang dapat mempengaruhinya antara lain ekonomi, sosial dan politik. Pada masa pandemi covid 19 ini, tidak hanya masyarakat yang merasakan dampak negatifnya namun juga pemerintah sebagai otoritas tinggi pelaksanaan kebijakan pemerintahan. Dari sisi ekonomi masyarakat miskin adalah masyarakat yang paling besar menerima dampak pandemi covid-19, banyaknya masyarakat yang kehilangan pekerjaan tentu mempengaruhi perekomian masyarakat hingga perekonomia negara, dari sisi sosial sudah saatnya pemerintah memberikan bantuan jika dilihat masa yang panjang dalam penanganan penyebaranan virus di tanah air, begitu juga dengan politik yang mana juga bersamaan dengan pemilihan kepala daerah tentu isu ini menjadi bagian sendiri dalam mensukseskan pelaksanaan program jaring pengaman sosial di masyarakat khususnya Pekanbaru.

\section{SIMPULAN DAN SARAN}

Program Jaring Pengaman Sosial yang ditujukan untuk membantu perekonomian masyarakat dalam masa pandemi covid1-19 khususnya di Pekanbaru telah dilaksanakan dari awal ditetapkannya program bantuan ini. Dari hasil peneltian yang telah dilakukan terdapat perbedaan cara dalam penentuan penerima program bantuan. Hal ini terkait degan isu sosial seperti terdapat pemekaran beberapa kecamatan yang mengakibatkan pendataan penduduk yang belum maksimal. Selain itu juga ada perbedaan penetapan dalam agen pelaksana koordinator lapangan di beberapa Kecamatan. Namun perbedaan tersebut tidak mengganggu dalam pelaksanaan program secara keseluruhan dan terkait standar sebagai tolak ukur keberhasilan kebijakan belum bisa dijelaskan karena memerlukan alat ukur yang tepat dan dapat menjadi rekomendasi penelitian berikutnya.

\section{DAFTAR PUSTAKA}

(2020, June 2). Dipetik December 1, 2020, dari www.kabar24.bisnis.com: https://kabar24.bisnis.com/read/20200602/15/1247422/pemerintah-klaimpenyaluran-bansos-pkh-telah-rampung

Agustino, L. (2016). Dasar-dasar Kebijakan Publik. Bandung: Alfabeta. 
Dharmakarja, G. I. (2017). Rekonstruksi Belanja Bantuan Sosial . Jurnal Substansi, Politeknik Keuangan Negara STAN , 375.

Hadirwardoyo, W. (2020). Kerugian Ekonomi Nasional Akibat PandemiI COVID-19. Jurnal BASKARA, vol. 2, no. 2.

Ihsanuddin. (2020, Agusutus 26). www.kompas.com. Dipetik September 15, 2020, dari Ada 7 Bantuan Pemerintah Selama Pandemi Covid-19, Berikut Rinciannya: https://nasional.kompas.com/read/2020/08/26/09222471/ada-7-bantuanpemerintah-selama-pandemi-covid-19-berikut-rinciannya?page=all

Karunia, A. M. (2020, Agustus 4). Imbas Corona, Lebih dari 3,5 Juta Pekerja Kena PHK dan Dirumahkan. Dipetik Sepetember 14, 2020, dari www.kompas.com:

https://money.kompas.com/read/2020/08/04/163900726/imbas-corona-lebih-dari3-5-juta-pekerja-kena-phk-dan-dirumahkan?page=all

Kurnia, F. (2020, September 10). www.gatra.com. Dipetik September 17, 2020, dari Pembenahan Data Jaring Pengaman Sosial di Riau Lamban: https://www.gatra.com/detail/news/489972/politik/pembenahan-data-jaringpengaman-sosial-di-riau-lamban

Mufida, A. (2020). Polemik Pemberian Bantuan Sosial Di Tengah Pandemic Covid 19 . ADALAH Buletin Hukum dan Keadilan , 159-166.

Nasruddin, R., \& Haq, I. (2020). Pembatasan Sosial Berskala Besar (PSBB) dan Masyarakat Berpenghasilan Rendah. SALAM; Jurnal Sosial \& Budaya Syar-i, 639-648.

Nugroho, A. (2020, Huni 4). Dipetik Desember 12, 2020, dari www.merdeka.com: https:/www.merdeka.com/peristiwa/mensos-perintahkankadinsos-pastikan-bantuan-pkh-di-tengah-pandemi-tepat-sasaran.html

Setiawan, K. (2020, September 5). Dipetik Desember 11, 2020, dari www.kemsos.go.id: https://kemsos.go.id/mensos-minta-sdm-pendamping-awasikelancaran-program-strategis

Sumodiningrat, G. (1999). Jaring Pengaman Sosial dan Pemberdayaan Masyarakat. Jurnal Ekonomi dan Bisnis Indonesia , 1-25.

Wibawa, S. (1994). Evaluasi Kebijakan Publik. Jakarta: PT. Raja Grafindo.

Wiranti, Sriatmi, A., \& Kusumastuti, W. (2020). Determinan Keputusan Masyarakat Kota Depok Terhadap Kebijakan Pembatasan Sosial Berskala Besar dalam Pencegahan Covid-19. Jurnal Kebijakan Kesehatan Indonesia , 117-124. 
www.pekanbaru.go.id. (2020, April 9). Dipetik September 17, 2020, dari Ada tiga Golongan Warga yang Bakal Dapat Bantuan: https://pekanbaru.go.id/p/news/adatiga-golongan-warga-yang-bakal-dapat-bantuan

www.setkab.go.id. (2020, Appril 9). Dipetik September 15, 2020, dari Pemerintah Berikan 6 Program Bantuan Tambahan Hadapi Pandemi Covid-19: https://setkab.go.id/pemerintah-berikan-6-program-bantuan-tambahan-hadapipandemi-covid-19/ 